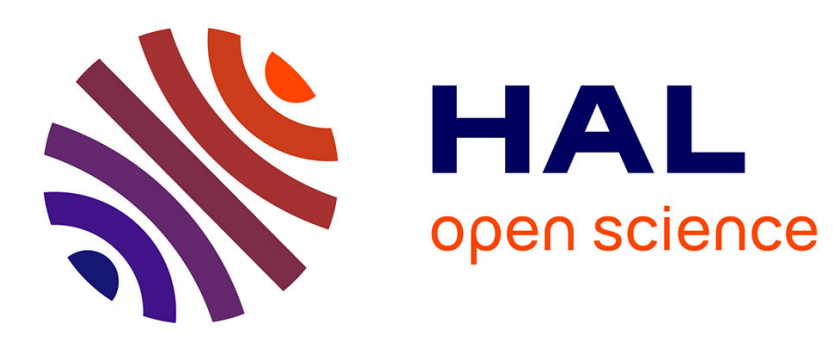

\title{
Tax policy and yardstick voting in Flemish municipal elections
}

\author{
Jan Vermeir, Bruno Heyndels
}

\section{To cite this version:}

Jan Vermeir, Bruno Heyndels. Tax policy and yardstick voting in Flemish municipal elections. Applied Economics, 2006, 38 (19), pp.2285-2298. 10.1080/00036840500427536 . hal-00581904

\section{HAL Id: hal-00581904 \\ https://hal.science/hal-00581904}

Submitted on 1 Apr 2011

HAL is a multi-disciplinary open access archive for the deposit and dissemination of scientific research documents, whether they are published or not. The documents may come from teaching and research institutions in France or abroad, or from public or private research centers.
L'archive ouverte pluridisciplinaire HAL, est destinée au dépôt et à la diffusion de documents scientifiques de niveau recherche, publiés ou non, émanant des établissements d'enseignement et de recherche français ou étrangers, des laboratoires publics ou privés. 


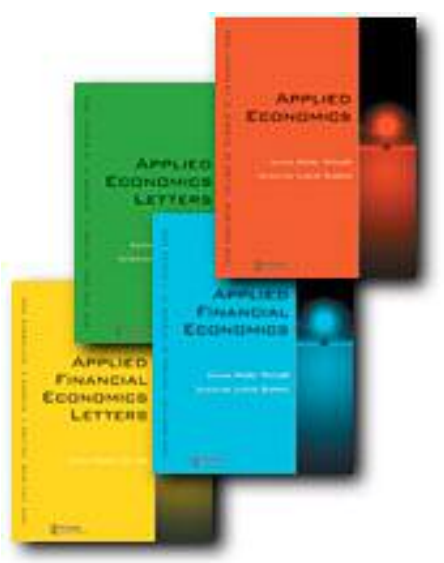

Tax policy and yardstick voting in Flemish municipal elections

\begin{tabular}{|c|c|}
\hline Journal: & Applied Economics \\
\hline Manuscript ID: & APE-05-0022.R1 \\
\hline Journal Selection: & Applied Economics \\
\hline $\begin{array}{r}\text { Date Submitted by the } \\
\text { Author: }\end{array}$ & 27-Jun-2005 \\
\hline JEL Code: & $\begin{array}{l}\text { H71 - State and Local Taxation, Subsidies, and Revenue < H7 - } \\
\text { State and Local Government|Intergovernmental Relations }<\text { H - } \\
\text { Public Economics }\end{array}$ \\
\hline Keywords: & tax policy, elections, yardstick competition, local government \\
\hline
\end{tabular}




\title{
Tax policy and yardstick voting in Flemish municipal elections
}

\begin{abstract}
.
Recent theoretical papers develop political agency models in which voters compare tax policy with that in neighbouring jurisdictions. In these yardstick competition models voters judge incumbents by comparing their policy with policy in neighbouring jurisdictions. We analyse municipal elections in Flanders during the period 1982-2000 and find empirical evidence for yardstick voting. Incumbents are punished for higher tax rates. Importantly, the electoral punishment also depends on tax rates in neighbouring municipalities. Higher rates in neighbouring municipalities are favourable for the incumbents.
\end{abstract}




\section{Introduction}

Several theoretical and empirical papers have explored the influence of tax policy (or fiscal policy) on elections. A recent addition to this literature has been the concept of yardstick voting. Besley and Case (1995) present a political agency model in which voters compare their tax policy with that in neighbouring jurisdictions. They show how yardstick voting can help voters identify bad incumbents. They find empirical evidence for yardstick voting in U.S. state elections in the period 1960-1988. Revelli (2002a) analyses local elections in the UK in the period 1979-1990, but finds no evidence of yardstick voting however. Investigating local elections in more than 3000 municipalities in 1995, 1999 and 2003, Bosch en Solé-Ollé (2004) find that property tax increases have a negative impact on the incumbent vote share, while property tax increases in neighbouring municipalities have a positive effect. Similarly, Agren (2004) finds evidence for yardstick voting in Swedish municipal elections in the period 1983-2002. She finds that voters punish higher income tax rates but that this electoral impact also depends on income tax rates in neighbouring municipalities.

Clearly, there is little empirical research on yardstick voting and evidence remains mixed. The Belgian political context is characterised by highly fragmented municipal governments and councils. We analyse whether the evidence for yardstick voting found in two-party contexts (Besley and Case, 1995) can be generalised to more complex political environments. Empirical work on economic voting has shown that this is not so self-evident. Powell and 
Whitten (1993) show that economic voting is weaker in those contexts where the clarity of responsibility of the government for economic policy is low. In a politically fragmented environment the responsibility for economic policy and tax policy is less clear. It is therefore possible that municipal governments are not held accountable for tax policy and as a consequence there is no yardstick voting. Our application on Flemish data allows us to examine whether yardstick voting also occurs in a politically fragmented environment. Analysing municipal elections in the period 1988-2000, we do find evidence for yardstick voting.

In section 2, we briefly review the existing theoretical and empirical literature on the electoral cost of taxation and more specifically the literature on yardstick competition. Section 3 gives a brief discussion of the institutional context and the role of local taxation in Flanders. Section 4 gives the results from our empirical analysis of Flemish municipal elections. We examine if tax policy has an impact on election results and if yardstick voting occurs. Thereby we concentrate on the two major local taxes: the local income tax and the local property tax rate. Section 5 concludes.

\section{The electoral cost of taxation: a review of the literature}

Following Downs (1957), rational individuals vote instrumentally. Voters vote for the party or politician from which they expect the highest utility gain. Their expectations on how parties will perform after the elections are based on party 
platforms and - for incumbent parties - also on past performance. A positive evaluation of the incumbent's past performance will translate into electoral gains. This logic underlies the responsibility hypothesis that has been the starting point of the empirical literature on vote and popularity functions. The central point of attention in that literature has been the electoral effect of macroeconomic variables. High economic growth, low inflation and/or unemployment have been found to positively affect the incumbents' election results or approval ratings (Mueller, 2003). In a way, the voter rewards the incumbent for making appropriate use of the policy instruments at its disposal. Still, these instruments - notably tax and expenditure policies - are not only instruments in macro-economic policy. They, first of all, allow responding to the voters' demand for public goods and redistribution. Further they determine how the cost of these goods is distributed over the population. Today, governments in industrialised countries raise considerable amounts of tax revenue. These taxes directly constrain the individual voter's capacity to spend on private goods and services. As such, it is natural to expect increased taxation to lead to electoral losses for the incumbent.

Several authors view elections in a principal-agent framework. ${ }^{1}$ The electorate is seen as the principal, and the incumbent government is the agent. Preelection promises are generally non-enforceable. But still as the incumbent wishes to be re-elected, voters can discipline the incumbent through retrospective voting (Persson and Tabellini, 2000). They either punish or reward the incumbent for past performance or they choose the most competent

${ }^{1}$ Among others, Ferejohn (1986), Rogoff (1990), Banks and Sundaram (1993), Besley and Case (1995), Persson and Tabellini (2000) and Revelli (2002a). 
government, using the information about past performance of the incumbent. A recent addition to this literature has been the concept of yardstick competition. If cost shocks are correlated with cost shocks in neighbouring jurisdictions, tax policy in those jurisdictions can yield information on the quality of the incumbent government and reduce asymmetric information between voters and the incumbent (Besley and Case, 1995; Wrede, 2001; Revelli, 2002; Bordignon, Cerniglia and Revelli, 2004). Accordingly, voters will use tax policy in neighbouring jurisdictions as a yardstick to overcome political agency problems, analogous to relative performance evaluation and tournaments in the literature on incentives in firms. ${ }^{2}$

Empirical evidence for an effect of tax variables (and fiscal variables in general) on elections has been well established. Early empirical research on the link between taxes and elections or incumbent popularity focuses on U.S. state data. Pomper (1968) and Turett (1971), in early papers on the electoral cost of taxation, do not find a consistent significant correlation between tax variables and the election results of U.S governors. Later studies do find an impact on gubernatorial elections. Eismeier (1979, 1983), Kone and Winters (1993), Niemi et al. (1995) and MacDonald and Sigelman (1999) look at the effects of specific tax policy decisions such as tax introductions or increases. They find a significant effect. An electoral impact is also found in Besley and Case (1995) and Lowry et al. (1998). Hansen (1999), however, finds no influence of the rate of change in tax revenue on the approval rating of governors. Peltzman (1992)

2 The idea of relative performance evaluation was introduced by Lazear and Rosen (1981), Holmström (1982) and Nalebuff and Stiglitz (1983). Shleifer (1985) introduced the concept of yardstick competition. The benefits of relative performance evaluation in decentralized government were first explored by Salmon (1987). 
finds evidence of an electoral cost of spending growth in presidential, senate and governor elections, but less solid evidence for an electoral cost of revenue growth. ${ }^{3}$ Still, in earlier work on U.S. presidential elections, Niskanen (1975, 1979) shows that an increase in federal tax revenues (or expenditures) has a significant negative effect on the vote for the American presidential candidate of the incumbent party.

Outside the US, an impact of tax variables on election results has been found in the UK (Pissarides, 1980; Gibson and Stewart, 1992; Gibson, 1996 and Revelli 2002), in Denmark (Paldam and Schneider, 1980), in Sweden (Hibbs and Madsen, 1981; Agren, 2004) in Canada (Happy, 1992; and Landon and Ryan, 1997) and in Spain (Bosch and Solé-Ollé, 2004). ${ }^{4}$

Several papers look for empirical evidence for yardstick voting. Besley and Case (1995) estimate the probability of defeat of incumbent governors in state elections in the period 1977-1988. They explore the effect of the change in income tax liability of joint filers in the 48 continental states. Importantly, they also look at the impact of the average tax change in the neighbouring states. They find that a tax change increases the probability of incumbent defeat while the neighbours' tax change reduces chances of incumbent defeat.

Revelli (2002a) investigates the impact of property tax rates on English district elections but finds no evidence for yardstick voting. One sample consists of "by

\footnotetext{
${ }^{3}$ An effect of spending growth on presidential elections is also found by Cuzán and Bundrick (1999).

${ }^{4}$ Brender (2003) finds an impact of fiscal performance (debt and debt change) in local elections in Israel.
} 
thirds" elections in 87 districts in the period 1979-1990. Another sample consists of "all out" elections in 122 elections for the years 1979, 1983 and 1987. No significant impact from the neighbours' tax rates on the incumbent vote share is found. In the by-thirds elections Revelli finds a significant effect of the local tax rates in the district itself. When he controls for the influence of national politics, however, the significance of the effect of the own tax rates disappears.

In a study of around 3000 Spanish municipalities in three local elections (1995, 1999 and 2003), Bosch and Solé-Ollé (2004) show that voters do take into account both property tax changes in the own municipality and property tax changes in neighbouring municipalities in municipal elections. Agren (2004) finds that voters evaluate Swedish municipal governments by looking at income tax rates in neighbouring municipalities in 276 elections in the period 1983-2002.

If voters take into account policy in neighbouring jurisdictions, policy makers are forced to care about policy in neighbouring jurisdictions too and engage in yardstick competition (Besley and Case, 1995). Besley and Case find evidence for tax mimicking among American states. Other evidence for tax mimicking includes Ladd (1992) for American counties, Heyndels and Vuchelen (1998) for Belgian municipalities, Solé-Ollé (2003) for Spanish municipalities, Bordignon et al. (2003) for Italian municipalities and Revelli (2001, 2002b) for English districts. ${ }^{5}$ Bordignon et al (2004) stress that evidence for tax mimicking is not sufficient evidence for yardstick competition. Mimicking can also be the result

${ }^{5}$ Ashworth and Heyndels $(1997,2000)$ and Heyndels and Ashworth (2003) present evidence that in Flemish municipalities politicians' opinions on whether a tax rate is high (or low) or on whether taxes should be increased, depend on prevailing tax rates in neighbouring municipalities. 
of tax competition. They develop a model in which yardstick competition can, under certain conditions, even lead to opposite results from mimicking. Crucially, Besley and Case (1995) present evidence that tax changes are only sensitive to tax changes in neighbouring states when the governor can run for re-election. As such, they show that the correlation between tax changes in neighbouring states is due to yardstick competition and not to another source. Similarly, Solé-Ollé (2003) shows that tax mimicking among Spanish municipalities is higher when the electoral margin is low. Finally, Bordignon et al. (2003) find spatial interaction in tax setting in Italian municipalities only when mayors do not face a term limit and are not backed by a large majority.

\section{Elections and tax policy in Flemish municipalities}

The Flemish region consists of 308 municipalities. Municipal government is important in Flanders, and more general in Belgium. Municipal revenues and expenditures have a sizable impact on the economy. Of total Belgian government expenditures, $13 \%$ are by local governments. ${ }^{6}$ Of total government investments, $44.5 \%$ are by local governments, which makes them the largest public investors in Belgium. Finally, $7.8 \%$ of all Belgian government taxes are raised by local governments (Dexia, 2004).

Flemish municipalities have a parliamentary political system using mandatory voting. Municipal elections take place every 6 years (the most recent election 
year being 2000). In each of the 308 municipalities councillors are elected using a system of proportional representation ("Highest Averages Imperiali"). Depending on the size of the municipality, between 7 and 55 councillors are elected. A local government (mayor and aldermen) is formed by the party or by a coalition of parties that possesses a majority of the seats.

The system of proportional representation leads to a highly diverse political landscape. In the most recent municipal elections, on average 5.16 parties presented themselves to the local voter. Whereas in some municipalities only two parties contested, the highest number of parties in a municipal election was as high as 13. Many of these parties have a local character with no or only a modest link to one of the six main "national" parties. For most of the parties, however, such a link was present and made explicit by using the "national" party name in the campaign. ${ }^{7}$

A major responsibility of the Flemish municipal governments is to set taxes. Tax revenues account for more than 40 percent of local revenues, the rest coming mainly from grants. Local governments have considerable freedom in choosing tax policy. This has led to a quite unique situation at the local government level in Flanders: municipalities use on average about 20 different taxes. Taken together, well over 100 different local taxes are in use. Still, while

6 This includes the provinces however.

7 The six "national" parties were: the ecologist Agalev, the Christian democratic CD\&V, the social democratic SP.a, the liberal democratic VLD, the nationalist VU and the extreme-right Vlaams Blok. For these parties, we put the word national between quotation marks, as their political action is limited to only the Flemish Community, i.e. the Flemish speaking subset of the Belgian population. In federal elections, Frenchspeaking ecologists, Christian democrats, ... participate too. These parties are separate entities without formal links with their Flemish speaking sister parties. At the 
this remarkable diversification is indeed a prominent characteristic of the Flemish municipal tax system, revenues are highly concentrated in only two taxes. Table 1 shows the most important municipal taxes in terms of revenue. The local income tax (LIT) and the local property tax (LPT) generate about 80 percent of all tax revenues. Their tax base is defined uniformly for the 308 Flemish municipalities. To test whether and how tax policy influences election results we can therefore focus on the electoral impact of those two tax rates. ${ }^{8}$

Table 1

about here

Both taxes are single rate surcharges on the federal income tax and the regional property tax respectively. The LIT is calculated as a percentage of the federal tax liability. The average local income tax rate in 2000 was $6.59 \%$. This means that residents in the average municipality pay $6.59 \%$ times their federal income tax bill. Local income tax rates ranged from 0 tot $8.5 \%$ in 2000 . It should be observed that the local income tax was more important in terms of revenues in 2000 than the property tax. The average LPT rate was $1073 \%$ in 2000 . This means that in the average municipality the LPT was 10.73 times the amount of the regional property tax on which it was a surcharge. The regional property tax itself corresponds to $2.5 \%$ of the assessed net rental value of the properties.

beginning of the seventies Belgian political families split up in Dutch speaking party and a French speaking party.

${ }^{8}$ Note that the local property tax is levied in all 308 municipalities; the local income tax is in use in 305 municipalities. 
So, the average local tax corresponds with $\left(10.73^{*} 2.5=\right) 28.8 \%$ of the net rental value. Given that - for budgetary reasons - no re-assessment took place since 1979 (when property values were expressed in 1975 prices) the tax base does not "really" reflect the net rental values. Since 1991, property values are adjusted for inflation (but not re-assessed). As a result, the link between the actual market (rental) value of properties and the tax weakened. Just as for the local income tax rate, important variation exists for the local property tax rate, which ranged from $438 \%$ to $2000 \%$ in 2000 .

\section{Empirical Analysis}

In this part we estimate a vote function. A vote function relates the votes obtained by the incumbent party (parties) - V - to economic, political and budgetary variables (Paldam and Schneider, 1980; Nannestad and Paldam, 1994; Revelli, 2002). Our vote function is specified as follows:

$$
\mathrm{V}_{\mathrm{it}}^{[\mathrm{t}-1, \mathrm{t}]}=\alpha \mathrm{V}_{\mathrm{it}-1}^{[\mathrm{t}-1, \mathrm{t}]}+\beta \mathrm{T}_{\mathrm{it}}+\gamma \sum_{\mathrm{j}=1}^{\mathrm{n}} \mathrm{w}_{\mathrm{ij}} \mathrm{T}_{\mathrm{jt}}+\delta \mathrm{X}_{\mathrm{it}}+\lambda_{\mathrm{t}}+\Omega \mathrm{P}_{\mathrm{it}}+\eta_{\mathrm{i}}+\varepsilon_{\mathrm{it}}
$$

$\mathrm{V}_{\mathrm{it}}^{[\mathrm{t}-1, \mathrm{t}]}$ is the vote share obtained at the elections in year $t$ in municipality $i$ by the party that was in government over the period $[t-1, t]$, that is since the previous election. In the case of coalition government the vote share corresponds with the sum of the shares of the coalition partners. As explanatory variable we include $V_{i t-1}^{[t-1, t]}$, the 
vote share obtained in the previous elections (at $\mathrm{t}-1$ ) by the same parties - those in power over the period $[\mathrm{t}-1, \mathrm{t}] \cdot{ }^{9} \mathrm{~T}_{\mathrm{it}}$ are tax and expenditure variables in municipality $i$ in election year $t$, while $T_{j t}$ are the tax and expenditure variables in neighbouring municipality $\mathrm{j} . \quad \mathrm{X}_{\mathrm{it}}$ is a vector of municipality characteristics thought to influence the vote share. We discuss the dependent variable $V_{i t}^{[t-1, t]}$ in section 4.1. and further present our empirical model and the explanatory variables in section 4.2. In section 4.3, we discuss the estimation method. The empirical results follow in section 4.4.

\subsection{Dependent variable}

We study the elections of 1988, 1994 and 2000 in 307 of the 308 Flemish municipalities. ${ }^{10}$ Our dependent variable is the percentage of the vote for the government parties. ${ }^{11}$ However the vote percentage of the government parties at the elections is not always available. Sometimes government parties do not participate at the elections following their government term. They may split up, or merge with another party - sometimes an opposition party - or simply disappear. From the data sources available it is not always possible to determine which party participating in the election corresponds to a government party. A party may participate in an election with a different name. However in that

\footnotetext{
${ }^{9}$ Note that this is not a lagged dependent variable. This is only a lagged dependent variable when the previous government remained in power, i.e. when $\mathrm{V}_{\mathrm{it}-1}^{[\mathrm{t}-1, \mathrm{t}]}=\mathrm{V}_{\mathrm{it}-1}^{[\mathrm{t}-2, \mathrm{t}-1]}$.

10 The municipality of Herstappe is considered as an outlier and is left out. The municipality, the smallest in Flanders, had only 85 inhabitants and 72 voters in 2000.

11 The electoral data come from the Elections Database of the Political Science Department of the Vrije Universiteit Brussel. Data on municipal governments come from the municipal data collection "Gemeentelijk Zakboekje" $(1985,1994,1999,2002)$.
} 
case, it is difficult to determine which party is the "successor" of the original party. Therefore we only consider these cases where government parties participate in the elections with the same name. ${ }^{12}$

We introduce the vote of the government party or parties in the preceding election as an explanatory variable to control for the influence for past events. Again, it is not always possible to calculate the vote percentage at the previous elections, because government parties did not always participate at these elections in the same form. A government party may be a part of a cartel list or a breakaway faction that formed a new party, and it is impossible to know which percentage of the vote this party would have received if it had participated in the previous elections in its current form.

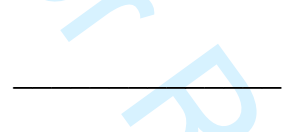

Table 2

about here

The consequence of this is that we do not have an observation for every election in every municipality (see Table 2). Our panel is unbalanced. Moreover, we also dropped these observations where a mayor or alderman (any member of the municipal government) was a candidate on a new list or the list of an opposition party in the next election. In those cases it is difficult to determine

${ }^{12}$ In this we follow Buelens and Deschouwer (1997). 
which parties are to be considered as the real government parties and accordingly which parties are to be held responsible for tax policy. As a result our dataset includes 689 observations - of the possible 921 observations. ${ }^{13}$

Why so much instability? Why do parties in Flemish municipalities change or disappear so often? A first reason is that many parties are so called "local" parties. These parties are often formed around one or more political personalities or issues in a municipality, and as such are not so stable. An example are the "lists of the mayor", parties created around the current mayor. By omitting a connection with a "national" party, they have the advantage of attracting voters and candidates of different ideologies and "national" parties. Of course, these parties only exist as long as that certain politician is in office or in politics. Another reason is the existence of cartel lists. The district magnitude in Flemish municipalities is not so large. It pays off to be a large party. Also, the distribution of seats is based on the Imperiali method, which is more advantageous to larger parties. As a consequence, parties benefit from presenting themselves to the voters together in a cartel list. However, cartel lists come and go, because of internal conflict.

\footnotetext{
${ }^{13}$ As we include the per capita expenditures in Flemish neighbouring municipalities in our regression, we loose an additional observation (the municipality of Voeren has no Flemish neighbours.) This leaves us with 688 observations. We did not have expenditure data for Brussels and Walloon municipalities.
} 


\subsection{Empirical model}

Next, we discuss the explanatory variables. $X_{i t}$, the vector of municipality characteristics includes two economic variables and one political variable. The literature on economic voting states that governments are held accountable for economic developments. While (macro-) economic policy is - of course mainly a federal and regional responsibility, local governments may have a (marginal) influence or may be held accountable by the electorate despite their objective inability to interfere. Therefore we include the real per capita income and the unemployment rate in our regression. We expect income to have a positive effect - prosperity translating into electoral support - and unemployment to negatively affect the incumbent's election result.

As political variable we include the number of government parties in the regression. When a government is made up of more parties, the responsibility of each party for policy and economic developments is less clear. ${ }^{14}$ The result is that fragmented governments are less held accountable for positive and negative developments (Powell and Whitten, 1993; Whitten and Palmer, 1999). Given that, on average, they are more punished for negative developments than they are rewarded for positive developments, fragmented governments suffer a smaller electoral loss (Nicholson et al., 2002). Also, voters can shift their votes between different government parties (Powell and Whitten, 1993). Accordingly, the number of government parties is expected to have a positive effect on the vote. 
The vector of tax instruments $\mathrm{T}$ includes the rates of the local income tax and the local property tax (LIT and LPT). We use the level of tax rates in the election year. We expect these to have a negative effect on the election result. The theory on yardstick competition suggests that voters use information on tax rates in neighbouring municipalities when deciding on their vote. We follow Besley and Case (1995) and Revelli (2002a) in looking at border sharing municipalities. They argue that geographic neighbours are likely to experience similar shocks and therefore information on tax variables in those municipalities may be a more informative yardstick to voters. Additionally, information about policy in those municipalities may be more easily available to voters. More specifically we create a spatial weight matrix $W=\left\{w_{i j}, i, j=1 \ldots 308\right\}$ where $w_{i j}$ is one if $i$ and $j$ are border sharing municipalities and is zero otherwise. The spatial weight matrix is then row-standardized (such that the row elements sum up to one). We then pre-multiply the vector of tax rates with the spatial weight matrix. This means we use the unweighted average of LIT and LPT rates in border-sharing municipalities as our neighbour variables. ${ }^{15}$ The level of tax rates in neighbouring municipalities is expected to have a positive impact on the election results. Finally, we include the per capita expenditures in the municipality. In as far as expenditures measure the quantity (and/or quality) of public output, we would expect a positive effect on the vote, as we already control for the cost of output though the tax rates. Analogously to the tax rates

\footnotetext{
${ }^{14}$ The argument is also true for divided government (Nicholson et al., 2002).

${ }^{15}$ We also include neighbouring municipalities in the Brussels and Walloon region, as the context is very similar. The local income tax and the local property tax are also the major local taxes and the tax bases of both taxes are defined on the federal level.
} 
we also include the average per capita expenditures in neighbouring municipalities. ${ }^{16}$

Some taxes have been found to be more electorally costly than others. This difference in political cost is generally attributed to the difference in visibility of taxes (Kone and Winters, 1993). Possibly, in the context of Flemish municipalities, the income tax and property tax rates could also have a different political cost. Concentrating on the specific characteristics of those taxes, we see two reasons why the local income tax is more likely to be underestimated than the local property tax and thus have a lower political cost. At the same time, two arguments can be found that suggest the income tax has higher political costs.

First, in contrast to the local income tax, the local property tax is more likely to be perceived as a truly local tax. Both taxes are surcharges. This means that - in practical terms - they are collected together with the federal (regional) tax on which they are based. As a consequence, taxpayers may fail to identify the "municipal component". The local component of the income tax is only a marginal fraction (around $7 \%$ ) of the total tax liability. In contrast, the local property tax is much larger than the regional tax on which it is based (the local component is about $90 \%$ of the tax liability). As a result, taxpayers may not distinguish between the respective components of the tax and consider "the income tax" as a federal tax and "the property tax" as a local one. ${ }^{17}$ To the

\footnotetext{
${ }^{16}$ As we do not have expenditure data for the Brussels and Walloon region, the average per capita expenditures in neighbouring municipalities take only into account Flemish neighbours.

17 However, a study by Heyndels (1989) shows both the local income tax and the local property tax are identified as a local tax by around half of the voters. Voters were asked to name the most important taxes in their municipality. Around $61 \%$ of the voters could
} 
extent that this is the case, the property tax is expected to have higher electoral costs for the incumbent government.

A second crucial difference is the collection process of both taxes. The local income tax is collected through a Pay As You Earn-system whereby employers withhold taxes. In the case of the property tax the whole amount is paid when the tax notice arrives, which is once a year. As the explicit payment of the whole amount is more visible, the property tax may have a larger political cost.

On the other hand, the local property tax is a tax on (mainly) residential property. For rented properties, it is formally paid by the owner and (partly) shifted to the renter. To the extent that renter illusion occurs, renters may not perceive (or underestimate) their tax burden. As a result, the local property tax may have a lower electoral cost among renters. ${ }^{18}$

In addition to these perception-related differences between both taxes, it should be noted that both differ also in terms of the definition of the tax base. While the income tax is residence based, the property tax is source based. This opens in the latter case - the possibility for tax exportation, possibly lowering the expected political cost associated with the property tax.

A final thing to note is that local elections do not take place in a (political) vacuum. The impact of national or regional politics on local elections is well

name a local tax. Of this group respectively $49.5 \%$ and $48.5 \%$ mentioned respectively the local property tax and the local income tax as a local tax.

${ }^{18}$ Heyndels and Smolders (1994) analyse the presence of different types of fiscal illusion in Flemish municipalities. They find no evidence for renter illusion. 
established (Heath et al., 1999; Jérôme and Lewis-Beck, 2000 and Revelli, 2002). In extreme situations, local elections can be considered as referenda for national politics and, consequently, the local election results may show little relationship with local developments and policies. Such a multi-level dependency may, in the Belgian situation, reveal itself by the fact that changes in the popularity of national parties translate into changes for the corresponding municipal parties. To capture this possibility, we included a set of party-year dummies $\left(\mathrm{P}_{\mathrm{it}}\right){ }^{19}$ In what follows, we will present the results with and without these dummies.

We also include year effects $\left(\lambda_{t}\right)$ and municipality fixed effects $\left(\eta_{i}\right) .20$ We discuss the municipality effects further in section 4.3 .

\subsection{Estimation method}

The estimation of our model presents several econometric challenges. First, as has been stated in the literature, the tax variables cannot be assumed to be exogenous. The error term in our model could be correlated with the tax rates. It has been shown in the literature on politico-economic models, that politicians adapt their policies according to their stock of popularity. For example Frey and Schneider (1978) show that the stock in popularity (more specifically the deficit in popularity necessary to secure re-election) affects tax policy in the UK.

\footnotetext{
${ }_{19}$ We include party-year dummies for the five "national" parties that participated in municipal government. A dummy is one if a certain party was part of municipal government in that election.

${ }_{20}$ These year effects measure the electoral change common to all governments in a certain year. They could for example measure the electoral rise of the extremist party Vlaams Blok (which was not present in any of the municipal governments).
} 
Schneider and Pommerehne (1980) show this for Australia. Therefore estimation with instrumental variables is in order.

Furthermore, there could be spatial correlation in the error term. In that case, the presence of the neighbours' tax variables introduces a bias (Revelli, 1999). This is the case if the error term follows a first order spatial auto-correlation process:

$\varepsilon_{\mathrm{it}}=\sum_{\mathrm{j}=1}^{\mathrm{N}} \mathrm{w}_{\mathrm{ij}} \varepsilon_{\mathrm{jt}}+\zeta_{\mathrm{it}}$. Again estimation with instrumental variables is more appropriate.

Besley and Case (1995) instrument the change in tax liability with year indicators and changes in the proportions of elderly and young. The neighbours' tax change is not instrumented. In a footnote they mention that they find no evidence for spatial correlation in the errors. Revelli (2002a) instruments the property tax rate in the district itself and in the neighbouring districts with values of the tax rates lagged two periods or more.

We present results both for OLS regressions and 2SLS regressions. In the 2SLS regressions, own tax rates and per capita expenditures are instrumented by the proportion of young people and elderly (as in Besley and Case, 1995), the average sale price of small and middle sized houses, the area of the municipality and finally the number of inhabitants. ${ }^{21}$ The same variables were used for the neighbouring tax rates and per capita expenditures. The average sale price of

${ }^{21}$ We had only data for house prices for the period 1990-2000. We therefore used data from 1990 for the election in 1988. 
small and middle-sized houses in the neighbouring municipalities is the average sale price in Flemish neighbouring municipalities only. Several municipalities have Brussels or Walloon neighbours and we include them to create our neighbours' tax variables. However our dataset of house prices did only include Flemish municipalities.

We estimate the OLS and 2SLS regressions both with and without municipality fixed effects. ${ }^{22}$ We present $\mathrm{F}$ tests for the significance of the fixed effects. Note that, as we have only three time periods, including municipality effects in our regression results in a loss of relatively many degrees of freedom.

The inclusion of fixed effects in our regression can lead to bias if the other variables are not strictly exogenous. The presence of a lagged dependent variable in a fixed effects regression is therefore problematic as it is certainly not strictly exogenous. Accordingly, there could be an endogeneity problem with the previous vote share of the current government parties. It should be observed that the previous vote share of the current incumbent is not a lagged dependent variable in the strict sense. A lagged dependent variable would be the previous vote share of the previous incumbent. This may or may not be the same party as the current incumbent. However, the previous vote share of the current incumbent is equal to the lagged dependent variable in case there is no turnover of power. Consequently the variable may still be problematic in a fixed effects regression. 
Revelli (2002a) is confronted with the same problem. His dependent variable is the vote share for the incumbent party and his regression also contains the vote for this party in the previous election. The regression includes district-party fixed effects. Following Arellano and Bond (1991), Revelli therefore takes first differences to get rid of the fixed effects. As the lagged vote variable is now correlated with the error term, he then instruments this variable with the incumbents' vote shares lagged two periods or more. The vote shares lagged two periods or more are valid instruments when there is no serial correlation in the error term - a test for second order correlation in the error term of the first differenced equation is reported. Equivalently, the tax variables are instrumented with values lagged two periods or more.

We think, however, that the Arellano-Bond estimator is not appropriate in our case, given the high turnover rate of power, which is typical of a multi-party system. ${ }^{23}$ We therefore present only OLS and 2SLS regressions.

\subsection{Results}

First we estimate pooled OLS regressions. Results are shown in Table 3. We show regressions with and without party-year dummies to control for the impact of national politics. The results are broadly similar for the two regressions. A Wald test shows that the party-year dummies are jointly

22 In these 2SLS regressions the area of the municipality and the neighbouring municipalities are dropped as instruments, as the first-stage regressions also include fixed municipality effects and the area variables are time-invariant.

${ }^{23}$ Moreover, our dataset is composed of only three time periods. Taking first differences would imply that we are left with only two time periods and lose a significant amount of observations. With only two time periods left, we would also not be able to present a 
significant, implying there is a national effect on municipal elections. We also present more efficient regressions in which insignificant variables were left out one by one. ${ }^{24}$

The vote percentage in the previous election has as significant positive impact, as expected. Also the number of government parties has the expected significant positive effect on the vote for the government parties. This confirms that fragmented governments lose fewer votes. The reason could be that it is less clear which party voters should hold responsible for policy or that vote swings between the government parties are possible.

Table 3

about here

Of the economic variables the unemployment percentage has no effect on the vote. This is not surprising as most policy instruments to fight unemployment are in the hands of the federal and regional government. Per capita income however has a significant negative impact on the vote for the incumbent parties. A possible explanation is that at lower levels of per capita income, voters tend to stay with or go back to traditional government parties, reminding of the

test for second-order autocorrelation, which is necessary to test the validity of the method.

${ }^{24}$ We also leave out insignificant party-year effects. The Wald test is for the remaing party-year effects. 
“clientele hypothesis" by Rattinger (Rattinger, 1981, 1991). Separate regressions (not shown here) show us that income has indeed a significant positive impact on the vote of the Green Party, a party that was in power in only a few municipalities. Per capita income also positively affects the vote of the extreme right Vlaams Blok, a protest party that has never been in power. This suggests that less traditional parties fare better at higher levels of income and that traditional government parties fare better at lower levels of income.

The main objective of our analysis was to find out if tax policy has an impact on election results. First, we find that per capita expenditures have no impact on the election results. This is not surprising, as what we really would like to include in our regression is the quality and/or quantity of public output. Measures of this are difficult to find however. The relation between expenditures and the quality of public output is indeed tenuous. Nannestad (2003) for example finds that there is no relationship between municipal expenditures spent on schooling and the quality of schooling.

We do find an electoral impact of the tax rates. The level of the property tax rate has a significant negative influence on the vote for the government parties. This shows that tax policy has indeed an effect on elections: incumbent parties are punished for higher tax rates. The income tax rate has also a negative impact on the vote, although not significant. This could indicate that property taxes have a higher electoral cost. As mentioned earlier, this could be due to the fact that the local income tax is less perceived as a local tax. Also, income taxes are withheld by the employer, whereas the collection of the property tax is more explicit. 
The average local property tax rate in the neighbouring municipalities has a significant positive impact on the election result. Also the neighbours' income tax rate has a positive though insignificant effect. This proves that voters indeed use tax rates in neighbouring municipalities as a yardstick to evaluate tax policy in their own municipalities.

In Table 4 we show the results for the OLS regressions including fixed municipality effects. The results are not in line with the previous findings. Per capita income loses its significant effect. More importantly for our analysis, the average property tax rate in the neighbouring municipalities does not have a significant effect on the vote anymore. The property tax rate in the municipality itself continues to have a significant negative effect on the vote for the incumbent parties. Note that the municipality fixed effects are not jointly significant at $5 \%$ in the first regression. They are however significant at $10 \%$. In the more efficient regression and in the regressions including party-year dummies they are strongly significant.

Table 4

about here

Next we show the 2SLS regressions in which tax and expenditure variables were instrumented (Table 5). Again, we first show the regressions without municipality fixed effects. The Sargan tests do not reject our instruments. The previous vote, the number of government parties and the real per capita income 
have the same significant impact as in the OLS regressions. In the 2SLS regressions, not the property tax rate seems to have a significant electoral impact but the local income tax rate. The income tax rate has a significant negative impact on the election results. The income tax rate in the neighbouring municipalities has no significant effect. However, in a more efficient regression in which insignificant variables were left out, the neighbours' income tax rate has a significant positive impact on the vote. This strengthens the evidence that voters use tax policy in neighbouring municipalities as a yardstick.

Table 5

about here

Surprisingly, the per capita expenditures in neighbouring municipalities have a strongly significant negative impact, while there is no significant impact from expenditures in the municipality itself. We do not find a clear reason for this.

The regressions with party-year dummies show the same results. Note that this time the party-year effects are not jointly significant.

The coefficients of the income tax rate and the neighbours' income tax rate are economically important. A $1 \%$ higher LIT rate results in a $5.4 \%$ lower vote share (in the more efficient regression). A $1 \%$ higher LIT rate in the neighbouring municipalities leads to a $6.8 \%$ higher vote share. So, incumbents 
are only punished for a high tax rate if the LIT rate is lower in the neighbouring municipalities. They seem to interpret a higher than average rate as a sign of incompetence or of rent seeking and therefore vote for the opposition candidates.

Finally, we show the 2SLS regressions including municipality effects (Table 6). Only the previous vote, the number of government parties (and the party-year dummies) have a significant effect. The municipality effects are far from significant. We therefore prefer the 2SLS regressions without municipality effects.

Table 6

about here

\section{Conclusion}

In our empirical analysis of municipal elections in Flanders we find evidence for yardstick voting. More specifically, our 2SLS regressions show that incumbents are punished for higher income tax rates. Importantly, the electoral punishment increases with lower rates in neighbouring municipalities and equivalently decreases with higher rates in neighbouring municipalities. We thereby show that yardstick voting not only occurs in a two-party system such as the US 
(Besley and Case, 1995), but also in a more complex multi-party system such as Belgium. The political fragmentation of the councils and the municipal governments could be expected to lead to a reduced electoral accountability. However, we do find that voters hold incumbents accountable for tax rates that are out of line with the average rate in neighbouring municipalities. Our empirical evidence supports the view that under decentralised government voters can - through relative performance evaluation - reduce information asymmetry with the incumbent politicians and so, as Wrede (2001) puts it, "tame the Leviathan". By comparing tax rates (and incumbents) with those in neighbouring municipalities, voters can identify rent-seeking or incompetent incumbents and vote them out of office. While evidence for yardstick voting is relevant in itself, it is also relevant for the literature on tax mimicking. The analysis suggests that tax mimicking among municipalities, such as found in Heyndels and Vuchelen (1998) among Belgian municipalities, is - at least partly - due to yardstick competition and not only tax competition.

\section{Acknowledgements}

We thank participants at the EPCS Annual Meeting in Berlin 2004 as well as at the MICE seminar at the Vrije Universiteit Brussel for helpful comments. We especially thank John Ashworth, Benny Geys, Martin Paldam, Kurt Schmidheiny and an anonymous referee. We thank Jo Buelens for providing us with electoral data. 


\section{Bibliography}

Administratie Binnenlandse Aangelegenheden (2002) De Gemeentefinanciën 2002: De financiële toestand van de Vlaamse gemeenten op basis van de rekeningen van 2000, Ministerie van de Vlaamse Gemeenschap, Brussels.

Agren, H. (2004) Yardstick competition - the tax setting behavior of Swedish municipalities?, Unpublished Manuscript.

Arellano, M. and S. Bond. (1991) Some tests of specification for panel data: Monte Carlo evidence and an application to employment equations, Review of Economic Studies, 58, 227-97.

Ashworth, J. and B. Heyndels (1997) Politicians' preferences on local tax rates: an empirical analysis, European Journal of Political Economy, 13(3), 479-502.

Ashworth, J. and B. Heyndels (2000) A schema-theoretic approach to politicians' definitions on tax issues, Journal of Economic Psychology, 21, 21-42.

Banks, J. S. And R. K. Sundaram (1993) Adverse election and moral hazard in a repeated elections model, in Political Economy: Institutions, competition and representation, (Eds.) Barnett, W. A., Hinich, M. J. and N. J. Schoffield, Cambridge University Press, Cambridge.

Brender, A. (2003) The effect of fiscal performance on local government election results in Israel: 1989-1998, Journal of Public Economics 87, 2187-2205.

Besley, T. and A. Case (1995) Incumbent behavior: Vote-seeking, tax-setting and yardstick competition, American Economic Review, 85, 25-45. 
Bordignon, M., Cerniglia, F. And F. Revelli (2003) In search of yardstick competition: a spatial analysis of Italian municipality property tax setting, Journal of Urban Economics, 54, 199-217.

Bordignon, M., Cerniglia, F. And F. Revelli (2004) Yardstick competition in intergovernmental relationships: theory and empirical predictions, Economic Letters, 83, 325-333.

Bosch, N. And A. Solé-Ollé (2004) Yardstick competition and the political costs of raising taxes: An empirical analysis of Spanish municipalities taking into account the political context, Paper presented at the $60^{\text {th }}$ Congress of the IIPF, Milan, Italy, August 2004.

Buelens, J. and K. Deschouwer (1997) De gemeenten en de lokale politiek in het Brussels Hoofstedelijk Gewest, Res Publica, 39(1), 89-99.

Case, A. (1994) Taxes and the Electoral Cycle: How sensitive are governors to coming elections?, Business Review, March/April, 17-26.

Cuzán, A. G. And C. M. Bundrick (1999) Fiscal Policy as a forecasting factor in presidential elections, American Politics Quarterly, 27(3), 338-53.

Deschouwer, K. (1996) Nationale partijen en gemeenteraadsverkiezingen, in De dorpsstraat is de Wetstraat niet: Een onderzoek naar de opvattingen van plaatselijke woordvoerders van nationale partijen (Eds.) Beulens, J. and K. Deschouwer., VUBPRESS, Brussels.

Dexia (2004) De financiering van de lokale overheden in 2003, Dexia, Brussels.

Downs, A. (1957) An Economic Theory of Democracy, Harper \& Row, New York. 
Eismeier, T.J. (1979) Budgets and ballots: The political consequences of fiscal choice in Public Policy and Public Choice (Eds.) Rae, D. and T. Eismeier, Sage, Beverly Hills.

Eismeier, T.J. (1983) Votes \& taxes: The political economy of the American governorship, Polity, 15, 368-79.

Ferejohn, J. (1986) Incumbent performance and electoral control, Public Choice 50, $5-25$.

Frey, B.S. and F. Schneider (1978) A politico-economic model of the United Kingdom, The Economic Journal, 88, 243-53.

Gemeentelijk Zakboekje '85/’86 (1985) Kluwer, Antwerpen.

Gemeentelijk Zakboekje '94/'85 (1994) Kluwer Editorial, Zaventem.

Gemeentelijk Zakboekje 1999: Databank (1999) Kluwer Editorial, Diegem.

Gemeentelijk Zakboekje 2002: Databank (2002) Kluwer, Diegem.

Gibson, J. G. (1994) Voter reaction to tax change: the case of the poll tax, Applied Economics, 26, 877-884.

Gibson, J.G. and J.D. Stewart (1992) Poll tax, rates and local elections, Political Studies, 40, 516-13.

Hansen, S.B. (1999) Life is not fair: Governors' job performance ratings and state economies, Political Research Quarterly, 52, 167-188.

Happy, J.R. (1992) The effect of economic and fiscal performance on incumbency voting: The Canadian case, British Journal of Political Science, 22, 117-30. 
Heath, A., McLean, I., Taylor, B. And J. Curtice (1999.) Between first and second order: A comparison of voting behaviour in European and local elections in Britain, European Journal of Political Research, 35, 389-414.

Heyndels, B. (1989) Fiscale perceptie bij de gemeenteraadsverkiezingen, De Gemeente, 4, 159-63.

Heyndels, B. and J. Ashworth (2003) Self-serving bias in tax perceptions: Federalism as a source of political instability, Kyklos, 56 (1), 47-68.

Heyndels, B. and C. Smolders (1994) Fiscal illusion at the local level: Empirical evidence for the Flemish municipalities, Public Choice, 80, 32538.

Heyndels, B. and J. Vuchelen (1998) Tax mimicking among Belgian municipalities, National Tax Journal, 60, 89-101.

Hibbs, D.A., Jr. and H.J. Madsen (1981) The impact of economic performance on electoral support in Sweden, 1967-1978, Scandinavian Political Studies, 4 (1), 3350.

Holmström, B.R. (1982) Moral hazard in teams, Bell Journal of Economics and Management Science, 93(2), 284-64.

Jérôme, B. And M. S. Lewis-Beck, (1999) Is local politics local? French evidence, European Journal of Political Research, 35, 181-97.

Kone, S.L. and R.F. Winters (1993) Taxes and voting: Electoral retribution in the American states, The Journal of Politics, 55, 22-40.

Ladd, H. F. (1991) Property tax revaluation and tax levy growth revisited, Journal of Urban Economics, 30, 83-99. 
Landon, S. and D.L. Ryan (1997) The political costs of taxes and government spending, Canadian Journal of Economics, 30, 85-111.

Lazear, E. P. and S. Rosen (1981) Rank-Order Tournaments as Optimum Labor Contracts, Journal of Political Economy, 89(5), 841-64.

Lowry, R.C., Alt, J.E. and K.E. Ferree (1998) Fiscal policy outcomes and electoral accountability in American states, American Political Science Review, 92, 759-74.

MacDonald, J.A. and L. Sigelman (1999) Public assessments of gubernatorial performance. A comparative state analysis, American Politics Quarterly, 27, 201-15.

Mueller, D.C. (2003) Public Choice III, Cambridge University Press, Cambridge.

Nalebuff, B.J. and J.E. Stiglitz (1983) Prizes and incentives: towards a general theory of compensation and competition, Bell Journal of Economics, 14, 21-43.

Nannestad, P. (2003) It's not the Economy, Stupid! Municipal School Expenditures and School Achievement Levels in Denmark, Paper presented at the EPSC Annual Meeting in Aarhus, Denmark, April 2003.

Nannestad, P. and M. Paldam (1994) The vp-function: A survey of the literature on vote and popularity functions after 25 years, Public Choice, 79, 213-45.

Nicholson, S. P., Segura, G. M. And N. D. Woods (2002) Presidential Approval and the Mixed Blessing of Divided Government, The Journal of Politics, 64(3), 701-20.

Niemi, R.G., Stanley, H.W. and Vogel, R.J. (1995) State economies and state taxes: Do voters hold governors accountable?, American Journal of Political Science, 39, 936-57. 
Niskanen, W.A. (1975) Bureaucrats and Politicians, Journal of Law and Economics, $18,617-43$.

Niskanen, W.A. (1979) Economic and fiscal effects on the popular vote for the president in Public Policy and Public Choice (Eds.) Rae, D. and T. Eismeier, Sage, Beverly Hills.

Paldam, M. and F. Schneider (1980) The macro-economic aspects of government and opposition popularity in Denmark 1957-78, Nationalokonomisk Tidsskrift, $2,149-70$.

Persson, T. and G. Tabellini (2000) Political Economics: Explaining Economic Policy, MIT Press, Cambridge.

Powell, G.B. and G.D. Whitten (1993) A cross-national analysis of economic voting: Taking account of the political context, American Journal of Political Science, 37, 391-414.

Peltzman, S. (1992) Voters as fiscal conservatives, The Quarterly Journal of Economics, 107, 327-61.

Pissarides, C.A. (1980) British government popularity and economic performance, The Economic Journal, 90, 569-81.

Pomper, G.M. (1968) Elections in America: Control and Influence in American Politics, Dodd, Mead \& Company, New York.

Rattinger, H. (1981) Unemployment and the 1976 election in Germany: Some findings at the aggregate and the individual level of analysis in Contemporary Political Economy (Eds.) D.A. Hibbs and H. Fassbender, North-Holland Publishing Company, Amsterdam. 
Rattinger, H. (1991) Unemployment and elections in West-Germany in Economics and Politics: The Calculus of Support (Eds.) Norpoth, H., Lewis-Beck M.S. and J-D. Lafay, The University of Michigan Press, Ann Arbor.

Revelli, F. (2001) Spatial patterns in local taxation: tax mimicking or error mimicking?, Applied Economics, 33, 1101-1107.

Revelli, F. (2002a) Local taxes, national politics and spatial interactions in English district election results, European Journal of Political Economy, 18, 28199.

Revelli, F. (2002b) Testing the tax mimicking versus expenditure spill-over hypotheses using English data, Applied Economics, 14, 1723-1731.

Rogoff, K. (1990) Equilibrium Political Budget Cycles, American Economic Review, $80(1), 21-36$.

Salmon, P. (1987) Decentralisation as an Incentive Scheme, Oxford Review of Economic Policy, 3(2), 24-43.

Shleifer, A. (1985) A theory of yardstick competition, Rand Journal of Economics, 16(3), 319-27.

Schneider, F. And W. W. Pommerehne (1980) Politico-Economic Interactions in Australia: Some Empirical Evidence, The Economic Record, 56, 113-31.

Solé-Ollé, A. (2003) Electoral Accountability and tax mimicking: the effects of electoral margins, coalition government, and ideology, European Journal of Political Economy, 29, 685-713.

Turett, S. (1971) The Vulnerability of American Governors, 1900-1969, Midwest Journal of Political Science, 15, 108-32. 
Whitten, G.D. and H.D. Palmer (1999) Cross-national analyses of economic voting, Electoral Studies, 18, 49-67.

Wrede, M. (2001) Yardstick competition to tame the Leviathan, European Journal of Political Economy, 17, 705-21. 
Table 1: Five most important municipal taxes in terms of revenue in 2000

\begin{tabular}{|ll|}
\hline Tax & Percentage of total tax revenue \\
\hline Local Income Tax & $45.8 \%$ \\
Local Property Tax & $36.7 \%$ \\
Tax on Motor-vehicles & $2.2 \%$ \\
Environmental Tax & $1.3 \%$ \\
Tax on domestic waste & $1.1 \%$ \\
\hline
\end{tabular}

Source: Administratie Binnenlandse Aangelegenheden, 2002

Table 2: Missing or dropped observations

\begin{tabular}{|l|c|c|c|}
\hline Year & 1988 & 1994 & 2000 \\
\hline $\begin{array}{l}\text { Government party/ies }\left(\mathrm{G}_{\mathrm{it}}\right) \text { did not participate in } \\
\text { election } \mathrm{t}\end{array}$ & 49 & 82 & 52 \\
\hline $\begin{array}{l}\text { Government party/ies }\left(\mathrm{G}_{\mathrm{it}}\right) \text { did not participate in } \\
\text { previous election } \mathrm{t}-1\end{array}$ & 4 & - & - \\
\hline $\begin{array}{l}\text { Mayor or alderman }\left(\text { of } \mathrm{G}_{\mathrm{it}}\right) \text { participated in election } \\
\text { t as member of new party or opposition party }\end{array}$ & 22 & 12 & 12 \\
\hline Total & $74^{*}$ & 94 & 64 \\
\hline
\end{tabular}

* One observation belongs to the first and the second category, which is why the observations in 1998 do not sum up to 75 . 
Table 3: OLS regressions

\begin{tabular}{|c|c|c|c|c|}
\hline $\begin{array}{l}\text { Dependent variable: Vote } \\
\text { share government parties }\end{array}$ & (1) & (2) & (3) & (4) \\
\hline $\begin{array}{l}\text { Prior vote government } \\
\text { parties }\end{array}$ & $\begin{array}{l}0.783 \\
(22.34)\end{array}$ & $\begin{array}{l}0.789 \\
(22.68)\end{array}$ & $\begin{array}{l}.779 \\
(22.27)\end{array}$ & $\begin{array}{l}0.794 \\
(23.38)\end{array}$ \\
\hline $\begin{array}{l}\text { Number of government } \\
\text { parties }\end{array}$ & $\begin{array}{l}1.997 \\
(4.37)\end{array}$ & $\begin{array}{c}1.838 \\
(4.18)\end{array}$ & $\begin{array}{l}3.322 \\
(3.65)\end{array}$ & $\begin{array}{l}1.610 \\
(3.17)\end{array}$ \\
\hline Per capita income & $\begin{array}{c}-0.942 \\
(-1.77) \\
\end{array}$ & $\begin{array}{c}-0.756 \\
(-1.61) \\
\end{array}$ & $\begin{array}{c}-0.788 \\
(-1.49) \\
\end{array}$ & $\begin{array}{r}-1.065 \\
(-2.95) \\
\end{array}$ \\
\hline Unemployment rate & $\begin{array}{c}-22.240 \\
(-0.72)\end{array}$ & & $\begin{array}{c}-11.402 \\
(-0.37)\end{array}$ & \\
\hline Per capita expenditures & $\begin{array}{l}.318 \\
(0.23)\end{array}$ & & $\begin{array}{c}0.466 \\
(0.34)\end{array}$ & \\
\hline $\begin{array}{l}\text { Per capita expenditures } \\
\text { neighbours }\end{array}$ & $\begin{array}{c}-2.615 \\
(-1.29)\end{array}$ & & $\begin{array}{c}-2.647 \\
(-1.31)\end{array}$ & \\
\hline LIT rate & $\begin{array}{c}-0.473 \\
(-1.33)\end{array}$ & & $\begin{array}{c}-0.279 \\
(-0.79)\end{array}$ & \\
\hline LIT rate neighbours & $\begin{array}{c}0.774 \\
(1.08)\end{array}$ & & $\begin{array}{l}0.206 \\
(0.29)\end{array}$ & \\
\hline LPT rate & $\begin{array}{l}-.004 \\
(-2.24)\end{array}$ & $\begin{array}{c}-0.004 \\
(-2.66)\end{array}$ & $\begin{array}{c}-0.004 \\
(-2.34)\end{array}$ & $\begin{array}{c}-0.004 \\
(-3.03)\end{array}$ \\
\hline LPT rate neighbours & $\begin{array}{l}0.006 \\
(2.63) \\
\end{array}$ & $\begin{array}{c}0.008 \\
(3.57) \\
\end{array}$ & $\begin{array}{l}0.007 \\
(2.81) \\
\end{array}$ & $\begin{array}{l}0.006 \\
(3.19) \\
\end{array}$ \\
\hline 1994 year effect & $\begin{array}{c}-1.335 \\
(-1.33)\end{array}$ & $\begin{array}{l}-1.807 \\
(-2.06)\end{array}$ & $\begin{array}{l}3.620 \\
(1.93)\end{array}$ & $\begin{array}{l}3.776 \\
(2.95)\end{array}$ \\
\hline 2000 year effect & $\begin{array}{c}-1.864 \\
(-1.42)\end{array}$ & $\begin{array}{l}-2.320 \\
(-1.90)\end{array}$ & $\begin{array}{c}-0.363 \\
(-0.19)\end{array}$ & \\
\hline Intercept & $\begin{array}{c}11.326 \\
(1.88)\end{array}$ & $\begin{array}{l}-9.412 \\
(2.48)\end{array}$ & $\begin{array}{l}9.981 \\
(1.64)\end{array}$ & $\begin{array}{l}9.746 \\
(2.78)\end{array}$ \\
\hline Party-year effects & & & YES & YES \\
\hline $\begin{array}{l}\text { Wald test party-year } \\
\text { effects: } \text { Prob > F }\end{array}$ & & & 0.0001 & 0.0000 \\
\hline Adjusted $R^{2}$ & 0.482 & 0.482 & 0.504 & 0.506 \\
\hline Number of observations & 688 & 688 & 688 & 688 \\
\hline
\end{tabular}

Note: Values between brackets are $\mathrm{t}$-values. 
Table 4: OLS Regressions with fixed municipality effects

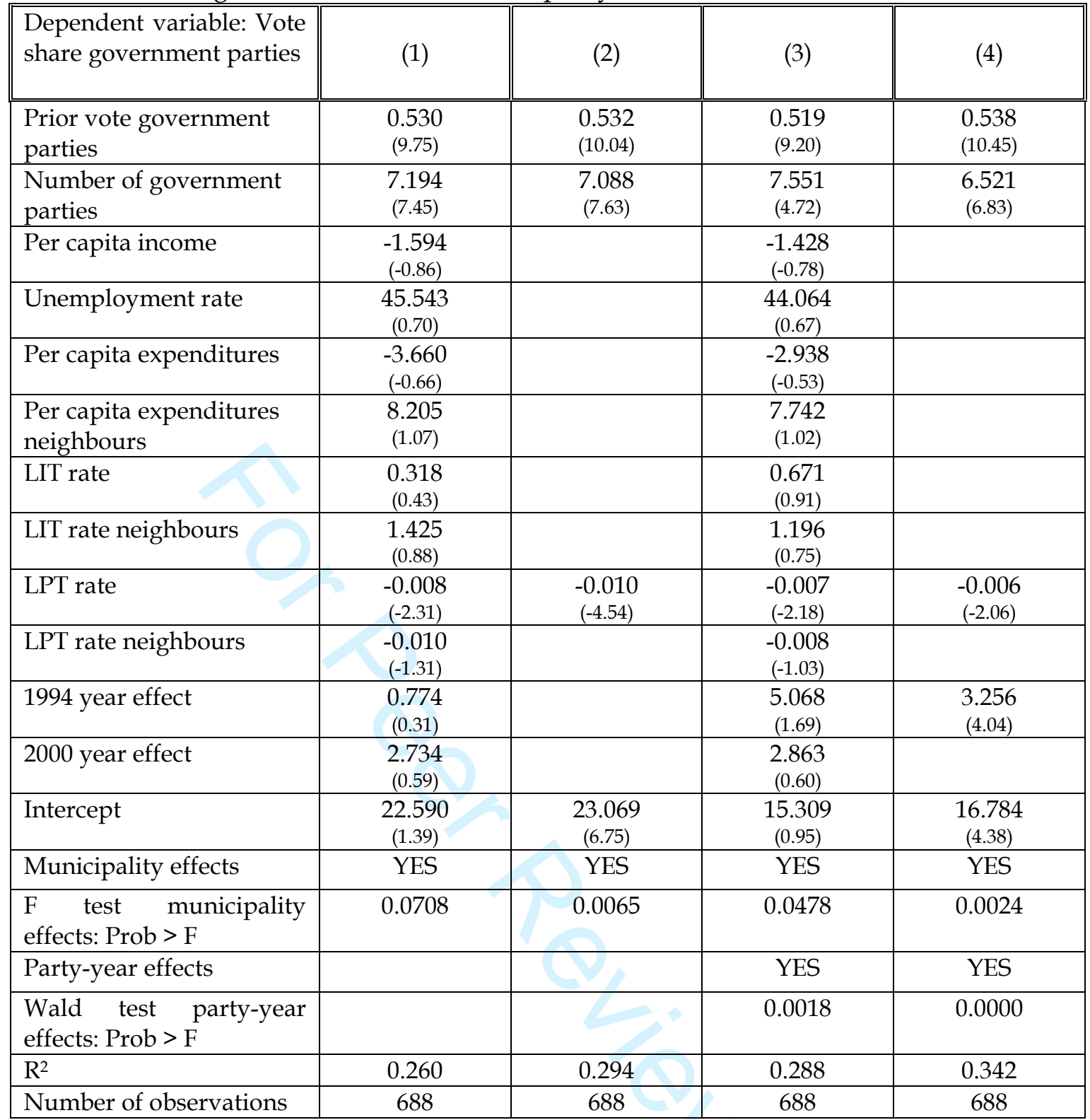

Note: Values between brackets are $\mathrm{t}$-values. 
Table 5: 2SLS Regressions

\begin{tabular}{|c|c|c|c|c|}
\hline $\begin{array}{l}\text { Dependent variable: Vote } \\
\text { share government parties }\end{array}$ & (1) & (2) & (3) & (4) \\
\hline $\begin{array}{l}\text { Prior vote government } \\
\text { parties }\end{array}$ & $\begin{array}{l}0.748 \\
(14.96)\end{array}$ & $\begin{array}{l}0.753 \\
(17.62)\end{array}$ & $\begin{array}{l}0.758 \\
(15.79)\end{array}$ & $\begin{array}{l}0.758 \\
(18.02)\end{array}$ \\
\hline $\begin{array}{l}\text { Number of government } \\
\text { parties }\end{array}$ & $\begin{array}{r}2.757 \\
(4.10)\end{array}$ & $\begin{array}{c}2.641 \\
(4.67)\end{array}$ & $\begin{array}{c}2.285 \\
(1.66)\end{array}$ & $\begin{array}{c}2.132 \\
(3.61)\end{array}$ \\
\hline Per capita income & $\begin{array}{c}-2.367 \\
(-1.90)\end{array}$ & $\begin{array}{r}-1.480 \\
(-2.88)\end{array}$ & $\begin{array}{c}-1.971 \\
(-1.61)\end{array}$ & $\begin{array}{c}-1.625 \\
(-3.24)\end{array}$ \\
\hline Unemployment rate & $\begin{array}{c}-21.468 \\
(-0.30)\end{array}$ & & $\begin{array}{l}8.323 \\
(0.12)\end{array}$ & \\
\hline Per capita expenditures & $\begin{array}{c}0.707 \\
(0.10) \\
\end{array}$ & & $\begin{array}{c}-2.008 \\
(-0.31) \\
\end{array}$ & \\
\hline $\begin{array}{l}\text { Per capita expenditures } \\
\text { neighbours }\end{array}$ & $\begin{array}{c}-17.580 \\
(-2.57)\end{array}$ & $\begin{array}{c}-11.619 \\
(-2.99)\end{array}$ & $\begin{array}{c}-17.774 \\
(-2.64)\end{array}$ & $\begin{array}{c}-12.954 \\
(-3.36)\end{array}$ \\
\hline LIT rate & $\begin{array}{c}-7.705 \\
(-2.77)\end{array}$ & $\begin{array}{l}-5.268 \\
(-3.37)\end{array}$ & $\begin{array}{c}-6.760 \\
(-2.31)\end{array}$ & $\begin{array}{c}-5.373 \\
(-3.50)\end{array}$ \\
\hline LIT rate neighbours & $\begin{array}{l}6.953 \\
(1.28)\end{array}$ & $\begin{array}{l}8.132 \\
(3.35)\end{array}$ & $\begin{array}{r}4.103 \\
(0.79)\end{array}$ & $\begin{array}{l}6.841 \\
(2.76)\end{array}$ \\
\hline LPT rate & $\begin{array}{c}0.0004 \\
(0.03)\end{array}$ & & $\begin{array}{c}0.0009 \\
(0.07)\end{array}$ & \\
\hline LPT rate neighbours & $\begin{array}{c}-0.002 \\
(-0.10)\end{array}$ & & $\begin{array}{c}-0.0003 \\
(-0.02)\end{array}$ & \\
\hline 1994 year effect & $\begin{array}{l}2.143 \\
(1.03)\end{array}$ & & $\begin{array}{l}6.062 \\
(2.15)\end{array}$ & \\
\hline 2000 year effect & $\begin{array}{l}4.033 \\
(1.38) \\
\end{array}$ & & $\begin{array}{l}3.551 \\
(1.12)\end{array}$ & \\
\hline Intercept & $\begin{array}{c}37.563 \\
(1.62)\end{array}$ & $\begin{array}{c}5.329 \\
(0.50)\end{array}$ & $\begin{array}{c}44.711 \\
(1.96)\end{array}$ & $\begin{array}{l}16.325 \\
(1.41)\end{array}$ \\
\hline Party-year effects & & & YES & YES \\
\hline $\begin{array}{l}\text { Wald test party-year } \\
\text { effects: } \text { Prob > F }\end{array}$ & & & 0.1488 & 0.0024 \\
\hline $\begin{array}{l}\text { Sargan test of } \\
\text { overidentifying } \\
\text { restrictions }\end{array}$ & $\begin{array}{c}\text { Chi-sq (4) } \\
1.684 \\
\text { p-value: } 0.79\end{array}$ & $\begin{array}{c}\text { Chi-sq (7) } \\
4.182 \\
\text { p-value: } 0.76\end{array}$ & $\begin{array}{c}\text { Chi-sq (4) } \\
2.891 \\
\text { p-value: } 0.576\end{array}$ & $\begin{array}{c}\text { Chi-sq (7) } \\
2.648 \\
\text { p-value: } 0.92\end{array}$ \\
\hline Adjusted $R^{2}$ & 0.098 & 0.270 & 0.212 & 0.296 \\
\hline Number of observations & 688 & 688 & 688 & 688 \\
\hline
\end{tabular}

Note: Values between brackets are $\mathrm{t}$-values. 
Table 6: 2SLS regressions with fixed municipality effects

\begin{tabular}{|c|c|c|}
\hline $\begin{array}{l}\text { Dependent variable: Vote } \\
\text { share government parties }\end{array}$ & (1) & $(2)$ \\
\hline $\begin{array}{l}\text { Prior vote government } \\
\text { parties }\end{array}$ & $\begin{array}{r}0.485 \\
(5.71)\end{array}$ & $\begin{array}{c}0.482 \\
(4.72)\end{array}$ \\
\hline $\begin{array}{l}\text { Number of government } \\
\text { parties }\end{array}$ & $\begin{array}{r}7.975 \\
(5.29)\end{array}$ & $\begin{array}{l}8.824 \\
(3.07)\end{array}$ \\
\hline Per capita income & $\begin{array}{c}0.608 \\
(0.17)\end{array}$ & $\begin{array}{l}1.221 \\
(0.37)\end{array}$ \\
\hline Unemployment rate & $\begin{array}{l}7.605 \\
(0.08)\end{array}$ & $\begin{array}{c}-11.633 \\
(-0.11)\end{array}$ \\
\hline Per capita expenditures & $\begin{array}{c}64.654 \\
(0.77)\end{array}$ & $\begin{array}{c}45.927 \\
(0.57)\end{array}$ \\
\hline $\begin{array}{l}\text { Per capita expenditures } \\
\text { neighbours }\end{array}$ & $\begin{array}{c}-18.298 \\
(-0.33) \\
\end{array}$ & $\begin{array}{c}-13.408 \\
(-0.26) \\
\end{array}$ \\
\hline LIT rate & $\begin{array}{c}0.586 \\
(0.14) \\
\end{array}$ & $\begin{array}{l}0.905 \\
(0.25) \\
\end{array}$ \\
\hline LIT rate neighbours & $\begin{array}{c}2.768 \\
(0.45)\end{array}$ & $\begin{array}{c}2.598 \\
(0.45)\end{array}$ \\
\hline LPT rate & $\begin{array}{c}-0.0008 \\
(-0.03) \\
\end{array}$ & $\begin{array}{c}0.0008 \\
(0.03)\end{array}$ \\
\hline LPT rate neighbours & $\begin{array}{c}0.002 \\
(0.05)\end{array}$ & $\begin{array}{l}0.010 \\
(0.27)\end{array}$ \\
\hline 1994 year effect & $\begin{array}{c}-8.806 \\
(-0.85) \\
\end{array}$ & $\begin{array}{l}-3.324 \\
(-0.39) \\
\end{array}$ \\
\hline 2000 year effect & $\begin{array}{c}-14.680 \\
(-0.78)\end{array}$ & $\begin{array}{c}-12.748 \\
(-0.82)\end{array}$ \\
\hline Intercept & $\begin{array}{c}-34.675 \\
(-0.53)\end{array}$ & $\begin{array}{c}-43.378 \\
(-0.74)\end{array}$ \\
\hline Municipality effects & YES & YES \\
\hline $\begin{array}{l}\text { F test municipality } \\
\text { effects: Prob > F }\end{array}$ & 0.9717 & 0.6961 \\
\hline Party-year effects & & YES \\
\hline $\begin{array}{l}\text { Wald test party-year } \\
\text { effects: Prob > F }\end{array}$ & & 0.0111 \\
\hline $\begin{array}{l}\text { Test of overidentifying } \\
\text { restrictions }\end{array}$ & $\begin{array}{c}\text { Chi-sq (2) } \\
1.652 \\
\text { p-value: } 0.44\end{array}$ & $\begin{array}{c}\text { Chi-sq (2) } \\
1.138 \\
\text { p-value: } 0.57\end{array}$ \\
\hline $\mathrm{R}^{2}$ & 0.045 & 0.097 \\
\hline Number of observations & 688 & 688 \\
\hline
\end{tabular}

Note: Values between brackets are t-values. 


\section{Appendix}

Table 7: Descriptive statistics (sample of 688 observations)

\begin{tabular}{|c|c|c|c|c|}
\hline Variable & Mean & $\begin{array}{l}\text { Standard } \\
\text { deviation }\end{array}$ & Minimum & Maximum \\
\hline $\begin{array}{l}\text { Vote share (in \%) } \\
\text { government parties at } \\
\text { election t: } V_{i t}\left(G_{i t}\right)\end{array}$ & 54.93 & 10.18 & 24.15 & 87.3 \\
\hline $\begin{array}{c}\text { Vote share (in \%) } \\
\text { current government } \\
\text { parties at election } \mathrm{t}-1 \text { : } \\
\mathrm{V}_{\mathrm{it}-1}\left(\mathrm{G}_{\mathrm{it}}\right) \\
\end{array}$ & 56.24 & 8.32 & 37.25 & 88.29 \\
\hline $\begin{array}{c}\text { Number of } \\
\text { government parties }\end{array}$ & 1.63 & 0.68 & 1 & 5 \\
\hline $\begin{array}{c}\text { Per capita income, in } \\
1000 \text { EUR }\end{array}$ & 5.49 & 0.96 & 3.21 & 8.88 \\
\hline Unemployment rate & 0.03 & 0.01 & 0.006 & 0.08 \\
\hline $\begin{array}{c}\text { Per capita } \\
\text { expenditures, in } 1000 \\
\text { EUR } \\
\end{array}$ & 0.67 & 0.25 & 0.23 & 2.18 \\
\hline $\begin{array}{c}\text { Per capita } \\
\text { expenditures } \\
\text { neighbours, in } 1000 \\
\text { EUR } \\
\end{array}$ & 0.69 & 0.17 & 0.42 & 1.82 \\
\hline LIT rate & 6.53 & 0.89 & 0 & 9 \\
\hline LIT rate neighbours & 6.58 & 0.51 & 3 & 8 \\
\hline LPT rate & 959.61 & 264.79 & 170 & 2000 \\
\hline LPT rate neighbours & 975.77 & 191.66 & 400 & 1650 \\
\hline
\end{tabular}


Table 8: Data sources

\begin{tabular}{|c|c|}
\hline Variable Name & Source \\
\hline $\begin{array}{l}\text { Vote share government } \\
\text { parties }\end{array}$ & \begin{tabular}{|} 
Own calculations \\
based on data from \\
the Electoral \\
Database of the Vrije \\
Universiteit Brussel \\
(Jo Buelens) and \\
"Gemeentelijk \\
Zakboekje" (1985, \\
1994, 1999, 2002) \\
\end{tabular} \\
\hline $\begin{array}{c}\text { Per capita income, in } 1000 \\
\text { EUR }\end{array}$ & $\begin{array}{c}\text { National Institute of } \\
\text { Statistics }\end{array}$ \\
\hline $\begin{array}{c}\text { Unemployment rate (number } \\
\text { of unemployed divided by } \\
\text { population) }\end{array}$ & \begin{tabular}{|c|} 
RVA/ONEM, \\
National Institute of \\
Statistics \\
\end{tabular} \\
\hline Per capita expenditures & $\begin{array}{c}\text { Flemish Ministry of } \\
\text { Interior Affairs }\end{array}$ \\
\hline Local Income Tax rate & $\begin{array}{c}\text { Flemish Ministry of } \\
\text { Interior Affairs }\end{array}$ \\
\hline Local Property Tax rate & $\begin{array}{c}\text { Flemish Ministry of } \\
\text { Interior Affairs }\end{array}$ \\
\hline Party-year dummies & \begin{tabular}{|c|} 
Own calculations \\
based on data from \\
the Electoral \\
Database of the Vrije \\
Universiteit Brussel \\
(Jo Buelens) \\
\end{tabular} \\
\hline
\end{tabular}

